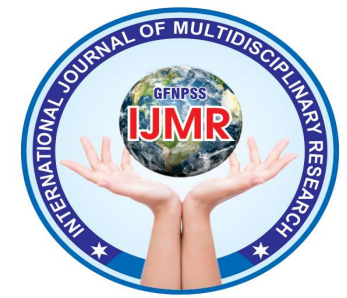

Original Article

ISSN (0): 2582-693X

\title{
A STUDY TO ASSESS THE EFFECTIVENESS OF PLANNED TEACHING PROGRAMME ON KNOWLEDGE REGARDING NOMOPHOBIA (MOBILE PHONE ADDICTION) AND IT'S PREVENTION AMONG ADOLOSCENT STUDENTS OF A SELECTED SENIOR SECONDARY SCHOOLS AT ALWAR
}

\author{
MRS. KUSUM LATA (RESEARCH SCHOLAR) \\ MAHARAJ VINAYAK GLOBAL UNIVERSITY DHAND, TEH. AMER, JAIPUR (RAJASTHNAN) \\ India.
}

Corresponding Email -: guddunsg2009@gmail.com

\begin{abstract}
:
Introduction: A Communication is the base of all relationships. The mobile phone is becoming the primary personal communication mechanism. Nomophobia is a term describing a growing fear in today's world - the fear of being without a mobile device, or beyond mobile phone contact.

Material and methods: A pre-experimental one group pre-test and post-test design was adopted, purposive sampling was used to select the 200 participants, the data generated by using investigator developed structured knowledge questionnaire, and content validity of investigator developed tool was obtained from experts of related departments.

Results: out of 200 adolescent students assessment of knowledge reveals the majority (85.55\%) of adolescent students had adequate knowledge on nomophobia and its prevention.

Conclusion: post-test knowledge score of adolescent students regarding nomophobia and its prevention reveals that majority $(85.55 \%)$ of participants were having adequate knowledge and $14.45 \%$ participants were having moderate knowledge.
\end{abstract}

Keywords: Effectiveness planned teaching programme, Knowledge, Nomophobia

\begin{tabular}{ccc}
\hline Received & Accepted & Available online \\
\hline $25 / 07 / 2021$ & $01 / 08 / 2021$ & $05 / 08 / 2021$ \\
\hline
\end{tabular}




\section{INTRODUCTION}

Communication meets fashion, if the primary symbol of teenage autonomy and status in the twentieth century was the car, in twenty first century it appears to be the cell phone. Although initially a symbol of wealth largely associated with male business executives, the cell phone is now synonymous with contemporary youth culture. It's the primary means of communication between teenage girls, allowing them to be reachable anywhere and anytime.

The mobile phone is becoming the primary personal communication mechanism worldwide. Not only is it a talking device on the move, but it is also a necessary social accessory. Its use has become a social phenomenon, taking place within a social context and influenced by perceptions of products, services, and social norms.

\section{NEED FOR THE STUDY:}

Adolescence is a period of greatly enhanced awareness. These years are also the time when mental and psychological development takes place. The adolescents are large in number and are the citizens and workers of tomorrow. This is the time of exploration of their own and they are more curious in nature. The swiftly changing global conditions are posing a great strain on the young people, modifying their behavior and relationships and exacerbating their health problems. The use of mobile phone has greatly changed the way the people communicate today especially the teenagers.

Problem Statement

"A Study To Assess the Effectiveness of

planned Teaching Programme on

Knowledge Regarding Nomophobia

(Mobile Phone Addiction) and its

Prevention Among Adolescent Students of

Selected senior secondary school at

Alwar"

\section{OBJECTIVES OF THE STUDY}

- To assess the existing knowledge regarding Nomophobia and its prevention among adolescent.

- To evaluate the effectiveness of planned teaching programme on knowledge regarding Nomophobia and its prevention among adolescent students.

- To find the association between post-test knowledge score of the adolescent students and their selected demographic variables. 


\section{RESEARCH HYPOTHESIS}

The study attempted to examine the following hypothesis: -

H0: There will be no significant association between level of knowledge scores regarding Nomophobia and its prevention among of adolescent students and their selected demographic variables.

H1: There will be significant difference between mean pertest and post-test Knowledge scores regarding Nomophobia and its prevention among of adolescent students.

$\mathrm{H} 2$ : There will be significant association between level of knowledge scores regarding Nomophobia and its prevention among adolescent students and their selected demographic variables.

\section{RESEARCH METHODOLOGY}

Research Approach: An evaluative research approach was a considered suitable for assessing effectiveness of planned teaching programme.

Research Design: The research design was a preexperimental one group pre-test and post-test design.

Population: The population was comprised of adolescent students from 11 class of oswal jain senior secondary school at Alwar.

Sample size: 200 adolescent students, who meet the criteria, were selected as sample for the present study from of oswal jain senior seconadary school at Alwar.

Sampling technique: Purposive sampling technique was used to select the participants.

\section{CRITERIA FOR SELECTION OF SAMPLE:}

\section{Inclusion Criteria}

- Adolescent students who are studying in 11 th class of Oswal jain senior secondary school.

- Adolescent students those who are present at the time of data collection.

\section{Exclusion criteria}

- Who are not willing to participate in the study?

- Who are not present during the data collection?

\section{Development of tool}

Keeping in view of the objective of the study a structured knowledge questionnaire was prepared based on the review of literature and in consultation with experts in the field of nursing, psychiatric and related disciplines.

\section{Validity of tool}

The content validity of the tool and PTP was ascertained in consultation with seven experts in the field of psychiatric nursing and related disciplines.

The $r$ Split half method was used to estimate homogeneity. The reliability of the test was estimate by using Karl Pearson's Correlation 
Coefficient. The reliability(r) of the tool was found to be 0.91 which indicated that the tool was reliable.

\section{RESULTS AND DISCUSSION}

SECTION 1: Analysis of Demographic characteristics of the sample The majority $56 \%$ of the respondents are in the age group of 16 years, $44 \%$ are in the age group of 17 years. About gender majority $62 \%$ of the respondents are females, $38 \%$ of the respondents are males. The maximum $46 \%$ of the respondents are Hindus. Most $62 \%$ of the respondents are from rural area. Most of the respondents $52 \%$ are belonged nuclear family. Majority of the respondents $80 \%$ of the respondents were having income of 10001$15000 /$-.the majority $24 \%$ of the respondents father studied up to primary. $26 \%$ of the respondents mother studied up to primary education, $.20 \%$ of the respondents were having previous knowledge about Nomophobia from friends and relatives, $62 \%$ of the respondents were having previous knowledge about Nomophobia from Mass media, and 18\% of the respondents were having previous knowledge about Nomophobia from self-reading.

\section{SECTION II: Analysis of pre-test and post-test} scores and effectiveness of planned teaching programme

\section{a) Analysis of pre-test knowledge scores}

Majority of $50 \%$ of respondents possess poor knowledge $26 \%$ of respondents possess very poor knowledge, $24 \%$ of respondents possess average knowledge.

\section{b) Analysis of post-test knowledge scores}

$88 \%$ of the respondents possess very good knowledge. $12 \%$ of the respondents possess good knowledge and none of them possess poor knowledge.

\section{SECTION III: ANALYSIS OF ASPECT WISE COMPARISON BETWEEN PRE- TEST AND POS TEST MEAN KNOWLEDGE SCORES OF RESPONDENTS ON NOMOPHOBIA}

In the aspect I knowledge regarding General Information about Nomophobia the mean \% in pre-test was $69.34 \%$ and in post-test was $97.33 \%$ with the enhancement of $28 \%$. In the aspect II Causes \& Symptoms the mean percentage in the pre-test was $32 \%$ and in post-test was $85.8 \%$ with the enhancement of $54.8 \%$.In the aspect III Effects of Nomophobia the mean percentage in the pre-test was $24.53 \%$ and in post-test was $80.66 \%$ with the enhancement of $56.13 \%$.In the aspect IV Prevention \& Treatment of Nomophobia the mean percentage in the pre- test was $37.67 \%$ and in post test was $81.66 \%$ with the enhancement of $44 \%$. The statistical paired ' $t$ ' test indicates the enhancement in the mean knowledge scores found to be significant at 5\% level for all the aspects under the study.

However the enhancement of knowledge found to be higher in knowledge regarding Nomophobia after structured teaching programme. Hence null hypothesis $\mathrm{H}_{0}$ is rejected and research hypothesis $\mathrm{H}_{1}$ is accepted.

GFNPSS-International Journal of Multidisciplinary Research, Volume 2, Issue 7, July 2021

DOI: $10.46376 / I J M R / 2.7 .2021, P$ a g e 721 | 32 


\section{SECTION IV: ANALYSIS OF OVER ALL PRE-TEST AND POST-TEST MEAN KNOWLEDGE ON NOMOPHOBIA}

In pre-test the mean knowledge score was 38.2\% and in post- test it was $85 \%$ with the enhancement of $47.65 \%$ with paired ' $t$ ' test value of $30.25^{*}$. It is significant at $5 \%$ level of significance.

The statistical paired ' $t$ ' implies that the difference in the pre test and post test knowledge score found to be statistically significant at $5 \%$ level $(\mathrm{p}>0.05)$ of significance. With paired' $t$ ' value of $30.25^{*}$, the findings reveals that there exists a statistical significance in the enhancement of knowledge score indicating the positive impact of intervention programme.

Hence null hypothesis $\mathrm{H}_{0}$ is rejected and the stated research hypothesis $\mathrm{H}_{1}$ is accepted.

\section{IMPLICATIONS OF THE STUDY}

Any research has its worth when it is implied to be beneficial to public.

The findings of the study have implications in the field of nursing practice, nursing

Education, nursing administration and nursing research.

\section{Nursing Practice}

Health education is an important tool for the health care agency. It is one of the most costeffective interventions to promote healthy living. Nurses working in the psychiatric units, educational institutions as well as in the community should be equipped with knowledge on nomophobia and its prevention.

\section{Nursing education}

The findings of the study would help the nurses to develop an in-sight into the prevention of Nomophobia. Nurses should have thorough knowledge regarding various aspects of health in order to provide comprehensive care to society. Nurses need to have in depth knowledge regarding behavioral problems so that they can motivate the adolescents about management and prevention of behavioral problems. This can be done by integrating education.

\section{Nursing Administration}

$>$ The study findings will help the administrator to arrange continuing education programme for nurses regarding Nomophobia. It helps to prepare adequate learning material for giving health education.

$>$ The nurse administrator should take active part in the police making, developing protocol, standing orders related health education.

\section{Nursing Research}

$>$ These study findings will identify the present knowledge about Nomophobia to know extent of necessary information to be given.

$>$ This study will motivate other investigator to conduct future studies regarding topics.

\section{RECOMMENDATIONS}

- The same study can be replicated on a larger 
sample and also at different settings.

- A comparative study can be done between rural and urban adults.

- A descriptive study on assessing the knowledge and attitude of adult on Nomophobia and its management can be done.

\section{LIMITATIONS}

1. The study was conducted on a small group of target population selected by purposive sampling technique. Hence generalisation is limited to the students of senior secondary schools at Alwar and sample size is limited to 200 .

2. Teaching plan was not based on learning needs of the subjects under the study but on the basis of the review of literature and investigators experience.

\section{CONCLUSION}

The focus of the study was to determine the "effectiveness of planned teaching programme on knowledge regarding Nomophobia among 11 th class students in a selected senior secondary at Alwar". A pre-experimental one group pretest post -test design was used in the study. The data was collected from 200 samples through purposive sampling technique. The conclusions drawn on the basis of the findings of the study Include:

1. The knowledge of the adolescent was not adequate before the introduction of PTP.
2. After the introduction of the PTP, the posttest findings showed the significant increase in the knowledge of adolescents on nomophobia.

3. PTP is proved to be one of the effective teaching strategies.

4. PTP can be kept for future reference when comparing with SIM.

5. PTP will be beneficial for adolescent students to understand their problems related to nomophobia and its prevention.

\section{BIBLIOGRAPHY}

1. Neha Jindal.Cell phone internet addiction rise among teens [Internet]. 2010 [cited 2017 Jan05].Available from URL: ://www.themedgur u.com/2010042 5/newsfeature/cell-phone-internetaddiction-rise among-teens-study86134423.html

2. Katz J E, \& Aakhus MA Mobile Communication, private talk, public performance. Cambridge, UK Cambridge University Press [Internet]. 2012 [cited 2017 Jan 02]. Available from URLhttp://www.google.com.in/search?q=m obile + communication + private + talk + public + performance $\&$ aqs $=\mathrm{ch}$ rome..69i57j0.32531j0j4\&client=msandroid-vivo \& sourceid $=$ chrome

3. Val Hooper, You Zhou Madrid. Mobile 
phones becoming a major addiction [Internet]. 2013 [cited 2017 Jan 27]:285.

4. Chóliz M. Mobile phone addiction: a point of issue. [1] Addiction [Internet]. 201[cited2017 Feb 05];105(2):37374.Available from: https://www. ncbi. nlm.nih.gov>pubmed

5. Gokul B. Mobile phone: A boon or bane, Term paper submitted to Govt. Polytechnic College, Kothamangalam, Kerala [Internet]. 2012. [cited 2017 Feb 07] Available from :https://

www.termpaperwarehouse.com>essay.on

6. Dikshit. June 9 at SLEEP, the 22nd Annual
Meeting of the Associated Professional Sleep Societies (APSS) [Internet]. 2011 [cited 2017 FEB 18]. Available from: http://www.medscape.com>viewcollection 7. Dikshit. June 9 at SLEEP, the 22nd Annual Meeting of the Associated Professional Sleep Societies (APSS) [Internet]. 2011 [cited 2017 FEB 18]. Available from: http://www.medscape.com>viewcollection

8. Davey. S Teenage cell phone use. Mobile phone addiction [Internet]. 2013 [cited 2017 Feb 20]. Available from: http://hubpages.com/hub/Indians- amongmost-addicted-mobile-phones-users. 